\title{
Ekonomická odolnost evropských venkovských regionů v období 2000 - 2016: př́ípadová studie čtyř států EU
}

\begin{abstract}
Adam PAVLÍK, Jan ŽENKA
Economic resilience of European rural regions in 2000 - 2016: a case study of four EU countries

Abstract: In this paper, we focus on economic resilience of selected rural NUTS3 regions in Germany, Italy, Czechia and Romania between 2000 and 2016. Our main aim is to provide empirical evidence of the long-term differences in economic resilience and volatility of rural regions across the national contexts. We ask, if and to what extent is it possible to identify similar regional patterns in various countries in terms of the reaction to the crisis: a) which rural regions improved/deteriorated in comparison to the economic performance of other rural regions in the respective country, b) which regions were characteristic by the high/low volatility of economic performance. We found highly diverse regional reactions to the crisis. While there were no clearly recognizable patterns of economic resilience, volatility was related to the changes in economic structure. Rural regions in Romania combined high economic volatility with the shift from agriculture mostly towards services.
\end{abstract}

Keywords: resilience, regional economic performance, unemployment, volatility, rural regions, Czechia, Italy, Germany, Romania

\section{Úvod}

Hospodářský vývoj evropských venkovských regionů byl v období ekonomické recese (2007 - 2010) provázen vysokou mírou nejistoty a volatility. Projevy recese byly na úrovni evropských zemí a regionů z hlediska načasování, délky a intenzity velice rozmanité (Fratesi, Perucca 2018). Tento článek reaguje na poměrně malý počet studií ekonomické odolnosti venkovských regionů věnovaných srovnání více různých států. Dosavadní analýzy odolnosti evropských regionů se zpravidla týkaly celé EU a neposkytovaly detailní vysvětlení regionálních rozdílů v jednotlivých státech (např. Annoni et al. 2019, Giannakis, Bruggeman 2019, Cainelli et al. 2019, Capello et al. 2015, Ezcurra 2011), nebo se soustředily na regionální diferenciaci vývoje ekonomické výkonnosti či zaměstnanosti jednoho vybraného státu (Pavel, Moldovan 2019, Urso et al. 2019, Ženka et al. 2019). Zaměřujeme se na hodnocení ekonomické odolnosti venkovských regionů na úrovni NUTS3 v Česku, Itálii, Německu a Rumunsku v období 2000 - 2016. Cílem je poskytnout empirickou evidenci dlouhodobých rozdílů v ekonomické odolnosti a volatilitě venkovských regionů napříc národními kontexty. Hlavní výzkumnou otázkou je, zda je možné ve vybraných státech najít sdílené rysy v reakci na krizi: a) které regiony zlepšily/zhoršily svou relativní pozici z hlediska ekonomické výkonnosti, b) které regiony se vyznačovaly vysokou/nízkou volatilitou ekonomické výkonnosti.

V kapitole 2 kromě definic hlavních pojmů diskutujeme hlavní faktory ekonomické odolnosti a volatility regionů. V kapitole 3 charakterizujeme zdroje dat a použité metody. V následující kapitole představujeme výsledky práce, které jsme rozdělili do čtyř částí: a) analýza makroekonomických trendů na úrovni států pro zarámování hospodářského cyklu, b) analýza ekonomické odolnosti a variability venkovských regionů NUTS3 v letech 2000 -2016, c) analýza volatility HDP a vývoje zaměstnanosti dle odvětvové struktury regionů NUTS3

DOI: https://doi.org/10.33542/GC2020-2-04 
v (post)krizovém období, d) syntéza výsledků a konfrontace odolnosti a volatility regionů. V kapitole 5 diskutujeme se závěry jiných autorů a v závěru shrnujeme hlavní zjištění a politické implikace.

\section{Definice a faktory regionální ekonomické odolnosti a volatility}

Pro potřeby článku se budeme držet definice regionální ekonomické odolnosti od Martina, Sunleye a Tylera (2015, p. 13), jakožto „schopnosti regionální nebo místní ekonomiky odolat tržním, konkurenčním a environmentálním otřesưm, nebo se z nich zotavit a v př́padě nutnosti podstupovat adaptační změny v ekonomické struktuře a sociálním a institucionálním uspořádánî‘. Volatilitou rozumíme kolísání ekonomické výkonnosti (či zaměstnanosti), měřitelné směrodatnou odchylkou a variačním koeficientem.

Ekonomická odolnost i volatilita jsou významně ovlivňovány sektorovou a odvětvovou strukturou hospodářství (Davies 2011). Venkovské oblasti mají obecně vyšší podíl zaměstnanosti v necyklických odvětvích, jako jsou napřr. zemědělství a potravinářský průmysl (Ezcurra 2011). Řada empirických studií prokázala pozitivní účinky zemědělství na schopnost venkovských regionů odolávat a zotavovat se z dopadů ekonomické recese (Giannakis, Bruggeman 2019, Faggian et al. 2018). Z tohoto důvodu lze předpokládat, že regiony s vyšším podílem zemědělství na HDP a zaměstnanosti budou charakteristické nižší volatilitou HDP a zaměstnanosti v (post)krizovém období 2008 - 2016. Mnoho empirických studií dokumentuje vyšší cyklicitu exportně orientovaných a cyklických odvětví zpracovatelského průmyslu a stavebnictví (Giannakis, Bruggeman 2019, Davies 2011). Za odvětví citlivá na krizi lze rovněž považovat některé služby s nižší znalostní náročností (např. služby vázané na cestovní ruch) nebo obchodní služby vázané na poptávku průmyslových firem (např. nákladní doprava, skladování). Výrazně cyklické jsou i znalostně náročné obchodní služby a kreativní odvětví, a to navzdory dlouhodobě růstovému trendu (Slach, Ženka 2017).

Ve venkovských regionech EU dochází k postupnému oslabování významu tradičních odvětví a posunu $\mathrm{k}$ technologicky a kapitálově náročným odvětvím zpracovatelského průmyslu s vyšší přidanou hodnotou (Pavlík 2018, Lengyel et al. 2017, Blažek, Netrdová 2012). Strukturální změny venkovských regionů jsou důsledkem ekonomické globalizace a integrace odvětví lokalizovaných na venkově do produkčních sítí přesahujících hranice regionů a států. Venkovské oblasti jsou čím dál častěji a ve vyšší intenzitě vystavovány konkurenci ze strany metropolitních, městských či jiných venkovských regionů (Ženka, Slach a Sopkuliak 2017). S rostoucí provázaností aktivit globálními produkčními sítěmi se zároveň zvyšuje riziko přenesení negativních dopadů ekonomické recese $\mathrm{z}$ metropolitních a městských regionů také na venkovské oblasti. Podle Martina (2012) je míra odolnosti regionů závislá na citlivosti jednotlivých odvětví na ekonomické recese a stupněm provázanosti odvětví v regionu i mimo něj.

Významný vliv na odolnost venkova mají též (př́mé) zahraniční investice, jejichž územní koncentrace na lokální úrovni (Casi, Resmini 2011) může zvýšit závislost venkovské ekonomiky na zahraničních rozhodnutích. Zahraniční firmy mohou být náchylnější k propouštění (Pavlínek, Ženka 2010), zejména dodavatelské firmy na nejnižších patrech produkčních sítí, které jsou vysoce závislé na dodavatelích vyššího řádu, často lokalizovaných v (zahraničních) metropolitních oblastech (Ženka, Slach a Sopkuliak 2017). Venkovské regiony závislé na zahraničním kapitálu se tedy mohou navzdory vyššímu zastoupení necyklických odvětví vyznačovat vysokou volatilitou ekonomické výkonnosti a zaměstnanosti.

Na druhou stranu je pro venkovské regiony dlouhodobě charakteristický vyšší podíl veřejných služeb na zaměstnanosti, které mohou v období recese plnit stabilizační roli (tzv. sheltered economies). Ve fázi zotavení a ekonomického růstu však regiony s vysokým zastoupením veřejných služeb nedosahují tak vysoké dynamiky růstu produktivity, jako jejich protějšky zaměřené na produkční odvětví (Fratesi, Rodríguez-Pose 2016). 
Mezi další faktory rozdílné odolnosti venkovských oblastí patří úroveň dosažené ekonomické výkonnosti před započetím recese. V regionech s vyšší ekonomickou výkonností a zaměstnaností častěji dochází $\mathrm{k}$ prudšímu poklesu ekonomické výkonnosti a rychlejšímu nárůstu nezaměstnanosti ve fázi recese (Pavlík 2016, Davies 2011), ale tyto regiony se mohou ekonomicky rychle zotavit (Giannakis, Bruggeman 2019). Fratesi a Perucca (2018) zjistili, že míra odolnosti regionů může být ovlivňována národními aspekty, kdy př́znivé makroekonomické podmínky měly pozitivní vliv na odolnost regionů v Německu nebo Polsku, nepříznivě se makroekonomické podmínky promítly do trajektorie regionů v Řecku, Itálii nebo Španělsku, u některých států nebyl vliv makroekonomických faktorů prokázán např. ve Francii nebo Velké Británii. Významným faktorem regionální ekonomické odolnosti může být též geografická blízkost ekonomicky rostoucích a odolných regionů. Ezcurra a Rios (2019) dokumentovali, že evropské regiony s nízkou ekonomickou odolností jsou častěji obklopené regiony s podobně nízkou odolností (platilo zejména pro Španělsko, Řecko, Itálii, Bulharsko a Rumunsko), naproti tomu vysoce odolné regiony jsou obklopeny jinými vysoce odolnými regiony (platilo zejména pro Německo, Belgii a Velkou Británii).

Abychom podchytili vliv výše diskutovaných faktorů regionální ekonomické odolnosti, přistoupili jsme k výběru zemí na základě následujících kontrastů:

a) Sektorová struktura hospodářství: rumunské venkovské regiony si zachovávají poměrně vysokou míru specializace na primární sektor (Pavel, Moldovan 2019). Venkovské regiony v Česku jsou charakteristické vysokým podílem výrobních sektorů na zaměstnanosti a HDP (Eurostat 2020). Německé a italské venkovské regiony mají obecně rozvinutější sektor služeb, ačkoli mnohé jsou též vysoce industrializované (Önnerfors et al. 2019).

b) Dosažený stupeň rozvoje: Česko a Rumunsko reprezentují nové členské státy EU s předpokladem konvergence ke starým členským zemím, které jsou zastoupeny Německem a Itálií.

c) Ekonomická výkonnost: vysoká heterogenita ekonomické výkonnosti německých (západovýchodní gradient) a italských (severojižní gradient) venkovských regionů kontrastuje s výrazně nižšími rozdíly mezi českými a rumunskými venkovskými regiony.

d) Vliv zahraničního kapitálu a postavení v globálních produkčních sítích: české firmy a pobočky jsou ve velké míře dodavateli průmyslových výrobků pro německé nadnárodní korporace, v podobné pozici jsou rumunské firmy oproti italským. Ekonomika českých a rumunských venkovských regionů je z velké části v zahraničním vlastnictví. Geografická blízkost německých a českých regionů se může projevit podobnou reakcí na recesi s určitým časovým posunem z důvodu intenzivní přeshraniční dělby práce a provázanosti lokálních trhů práce. Novější studie však nepotvrzují vliv západovýchodního gradientu na pozitivní jevy (Vaculík et al. 2017 - rozmístění inovativních firem) ani negativní jevy (Ženka et al. 2019 - nezaměstnanost).

V období hospodářského otřesu lze předpokládat dva scénáře vývoje venkovských ekonomik (Ženka et al. 2019):

a) Relativně stabilní hospodářský vývoj v (post)krizovém období vyplývající z rozmanitosti, necyklických odvětví a vyššího zastoupení veřejného sektoru.

b) Negativní vývoj vedoucí k hysterezi, způsobený ztrátou konkurenceschopnosti a zánikem místních odvětví náročných na pracovní sílu: velmi nízká odolnost a nízká míra zotavení v důsledku negativního trajektorie růstu (např. deindustrializace, depopulace nebo úpadek místních spotřebitelských odvětví).

Otázkou je, který scénář převládne ve studovaných venkovských regionech čtyř zemí EU. $\mathrm{V}$ odborné literatuře totiž nepanuje shoda $\mathrm{v}$ otázce, zda jsou venkovské regiony více či méně odolné než jiné typy regionů (Ženka, Pavlík a Slach 2017). 


\section{Data a metody}

Vycházíme z typologie městských a venkovských regionů (Urban - Rural Typology), kterou používá Evropská komise (Eurostat 2018). Typologie je založena na podílech městského a venkovského obyvatelstva v regionu. Určující je populační mřížka (population grid) o velikosti $1 \mathrm{~km}^{2}$. Městské jednotky (mř́žky) jsou definovány hustotou zalidnění (> 300 obyvatel $/ \mathrm{km}^{2}$ ) a populační velikostí (> 5000 obyvatel). Městské oblasti (shluky) tvoří sousední populační mř́žky, které splňují výše uvedená kritéria. Venkovské regiony jsou charakteristické nižší mírou urbanizace a populační velikostí. Typologie zahrnuje tři úrovně: a) predominantly urban regions - převážně městské regiony, podíl obyvatel žijících v městských oblastech (městské klastry) činí více než $80 \%$, b) intermediate regions středně urbanizované až urbanizované regiony, podíl obyvatel žijících v městských oblastech (městské klastry) činí $51-80 \%$ c) predominantly rural regions - převážně venkovské oblasti, podíl obyvatel žijících ve venkovských oblastech činí nejméně $50 \%$. Typologie je konstruována pro úroveň NUTS3 a její částečné omezení spočívá v tom, že nezohledňuje rozdíly ve velikosti měst, které mohou výrazně ovlivnit schopnost celého regionu reagovat na recesi (Capello et al. 2015) a zároveň mohou zkreslovat výsledky a průkaznost dosaženého poznání pro venkovské oblasti. Na úrovni NUTS3 v Česku, Itálii, Německu a Rumunsku je vymezeno celkem 163 venkovských regionů.

Průběh hospodářského cyklu: růst, recesi, oživení a zotavení analyzujeme na úrovni států. Sledujeme vývoj hrubého domácího produktu (HDP) a podíl nezaměstnaných osob (\%) ve věku 15 - 64 let na celkovém ekonomicky aktivním obyvatelstvu (dále jen nezaměstnanost) v letech 2000 - 2016. HDP je vhodným ukazatelem, reaguje velmi citlivě na změny poptávky, odráží různou výchozí úroveň ekonomické výkonnosti jednotlivých států a zahrnuje intervence veřejného sektoru. V tomto ohledu se jedná o komplexnější ukazatel než samotná hrubá př́idaná hodnota produkčních odvětví. (Ne)zaměstnanost reaguje na průběh hospodářského cyklu se zpožděním, přičemž zotavení regionálních trhů práce z dopadu ekonomického šoku může trvat podstatně déle než návrat nad předkrizovou úroveň HDP na obyvatele (Reinhart, Rogoff 2009). Nezaměstnanost tedy odráží (dlouhodobější) sociální dopady, čímž vhodně doplňuje ukazatel HDP.

Hlavním ukazatelem ekonomické odolnosti regionů bude vývoj HDP v paritě kupní síly na obyvatele v EUR $(€)$ v období 2000 - 2016. Regionální účty spravované Eurostatem (2020) pracují s jednotnou metodikou ESA2010 pro definici statistických pojmů a metod na úrovni NUTS. HDP je měřeno hrubou přidanou hodnotou v běžných cenách, kterou je možné dále standardizovat národní paritou kupní síly a na obyvatele. HDP bude měřeno ve dvou variantách: a) index změny HDP pro zachycení variability mezi regiony v letech $2000-2016$, b) variační koeficient HDP pro měření volatility a dopadů ekonomické recese $\mathrm{v}$ (post)krizovém období, do roku 2016. Hodnoty indexu a variačního koeficientu HDP venkovských regionů budou vyděleny (standardizovány) průměrem venkovských regionů dle př́slušných států. Tímto bude možné částečně zmírnit předpokládané nadměrné ekonomické rozdíly mezi vybranými státy a komparovat venkovské regiony jak na úrovni státu, tak i mezi sebou navzájem.

Doplňující vysvětlující proměnnou ekonomické odolnosti je vývoj odvětvové struktury zaměstnanosti, který sledujeme na jednodigitální úrovni NACE v období 2000 - 2016. Změny ve složení odvětvové struktury v (post)krizovém období budou měřeny prostřednictvím Finger-Kreininova Indexu (Finger, Kreinin 1979, dále jen FKI). Pro rozlišení faktorů odolnosti sledujeme též objem investic zahraničních firem ve venkovských regionech Česka a Rumunska v letech 2005 - 2016.

Pro shrnutí trendů konstruujeme jednoduchou typologii venkovských regionů založenou na kombinaci ekonomické odolnosti a volatility. Venkovské regiony členíme do čtyř skupin: 
1. Regiony odolné a stabilní: nadprůměrná dynamika růstu HDP v letech 2000 - 2016 a podprůměrná volatilita HDP (variační koeficient) v letech 2008 - 2016, průměrem je vždy myšlena průměrná hodnota venkovských regionů v daném státě.

2. Regiony odolné a volatilní: nadprůměrná dynamika i volatilita vývoje HDP ve sledovaných obdobích, regiony dlouhodobě ekonomicky rostoucí navzdory krátkodobým dočasným kolísáním ekonomické výkonnosti.

3. Regiony stagnující a stabilní: podprůměrná dynamika i volatilita vývoje HDP.

4. Regiony stagnující a volatilní: podprůměrná dynamika, nadprůměrná volatilita vývoje HDP ve sledovaných obdobích.

Primárním zdrojem datových podkladů je Eurostat (2020), který obsahuje data za ekonomickou výkonnost a odvětvovou strukturu zaměstnanosti NUTS3 i nezaměstnanost na úrovni států. Podkladem pro analýzu vývoje zahraničních investic bude databáze European Restructuring Monitor - ERM (Eurofond 2019). Tento obsahuje vybrané údaje za restrukturalizaci odvětvové základny dle vývoje zaměstnanosti na úrovni firem.

\section{Výsledky}

Analýza makroekonomických trendů (vývoje nezaměstnanosti a HDP) ukazuje, že se hospodářský pokles nejdříve projevil v Itálii, v níž byla zároveň zachycena také druhá fáze recese provázená poklesem zaměstnanosti i HDP. V Česku, Rumunsku a Německu bylo načasování hospodářské krize podobné, rozdílné však byly reakce regionů a trvání recese. V Česku trvalo zotavení déle a taktéž byla zjištěna druhá fáze recese doprovázená poklesem nezaměstnanosti (obr. 1). Rumunsko bylo charakteristické fluktuací HDP i nezaměstnanosti, značící vyšší citlivost hospodářství, po celé studované období. Hospodářská recese se v Německu projevila pouze krátkodobě, lze tedy predikovat vysokou odolnost německých venkovských regionů a v př́ípadě italských a rumunských naopak nižší ekonomickou odolnost vůči změnám a narušení. HDP měl tendenci $\mathrm{k}$ dřívějšímu zotavení než nezaměstnanost.

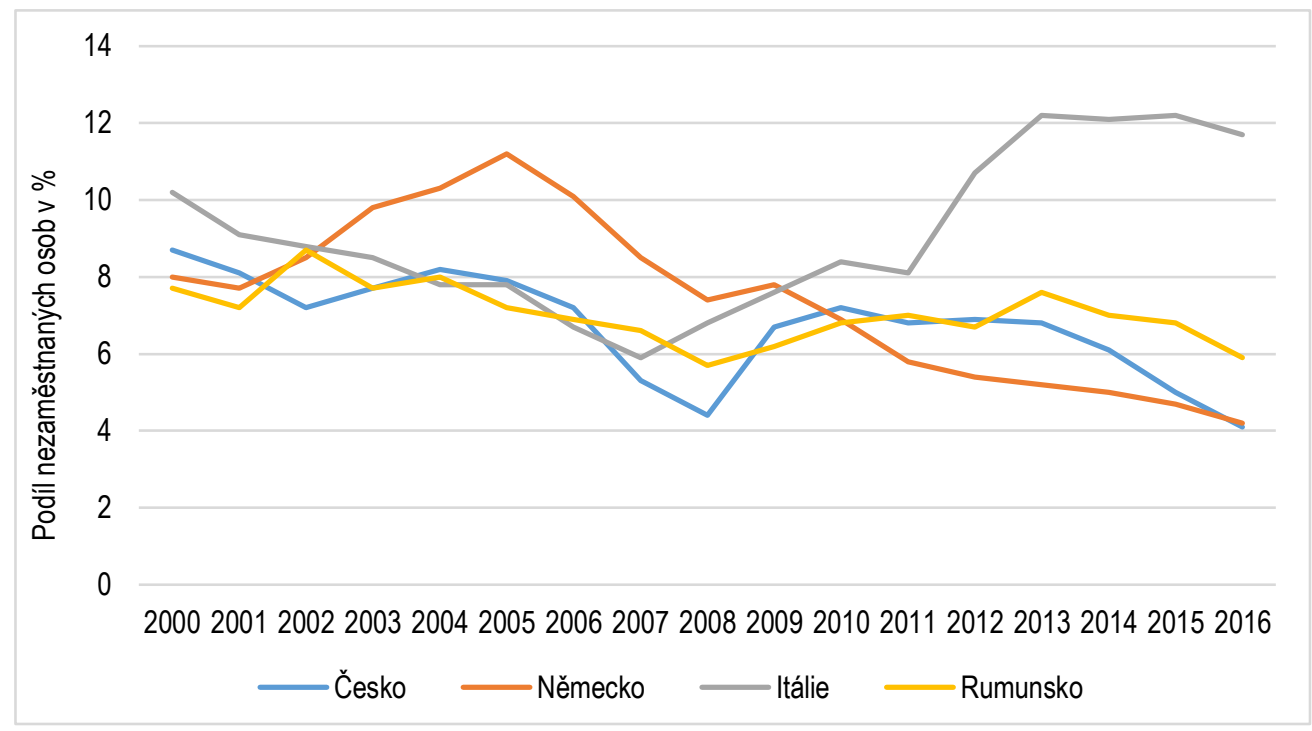

Obr. 1. Vývoj nezaměstnanosti na úrovni států v letech 2000 - 2016;

Zdroj: Eurostat (2020), vlastní zpracování. Pozn.: Data jsou vztažena k národní úrovni, nikoli pouze $k$ venkovským regionuim. 
Druhá část výzkumu se zaměřila na analýzu ekonomické odolnosti venkovských regionů NUTS3 v letech 2000 - 2016. Podle očekávání byla zjištěna vysoká prostorová variabilita růstu HDP. Rozdílná startovací pozice regionů ovlivňovala dynamiku růstu. Regiony s nižším HDP v roce 2000 zpravidla dosáhly vyšší dynamiky růstu HDP v období 2000 - 2016 a relativně si zlepšily pozici z hlediska ekonomické výkonnosti v dané zemi. Tento vliv byl nejvíce patrný v Rumunsku a Německu, a naopak nejméně v Itálii. V Rumunsku dosáhly nejvyšší dynamiky růstu HDP méně rozvinuté venkovské regiony s výhodnou polohou a dobrou dopravní dostupností, ležící v blízkosti rozvinutějších metropolitních a městských oblastí - regionů Bukurešt' a Ilfov, Kluž, Constanta nebo exponovaných hraničních přechodů (obr. 2). V Německu nejrychleji rostly venkovské regiony ležící v centrální a východní části - venkovské oblasti v blízkosti státní hranice s Českem v regionech Niederbayern a Oberpfalz a na území bývalé Německé demokratické republiky (NDR). V Česku se vyšší dynamikou růstu HDP vyznačovaly Plzeňský kraj a kraj Vysočina, pomalejším růstem Jihočeský kraj. V Itálii nejrychleji rostly rozvinutější venkovské regiony na severu země, nejpomaleji oblasti ve střední Itálii a Sardinii. V Itálii se jako v jediném ze čtyř analyzovaných států zvýšila variabilita HDP mezi venkovskými regiony, v ostatních zemích došlo ke konvergenci ekonomické výkonnosti.

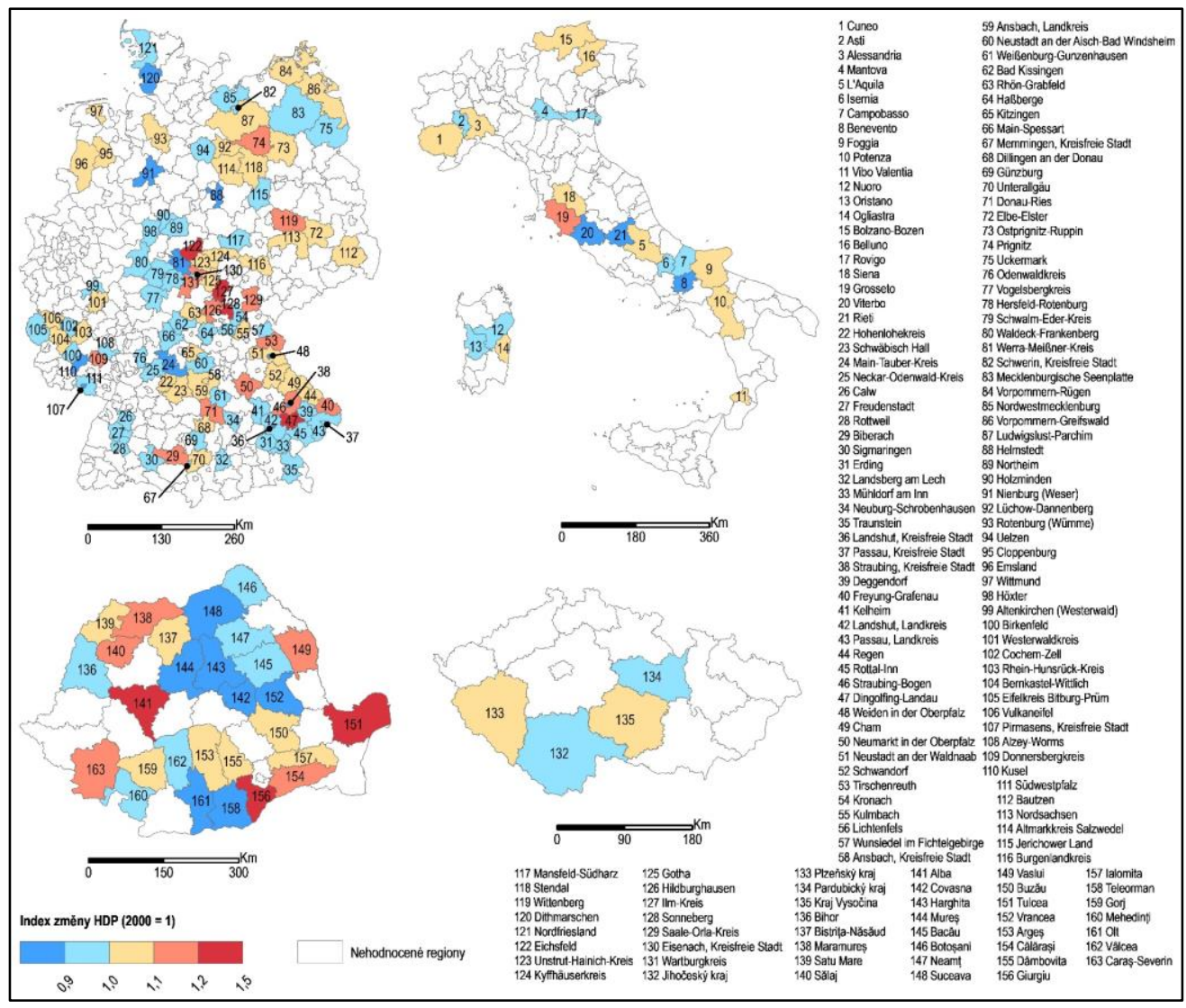

Obr. 2. Index změny HDP venkovských regionů NUTS3 z hlediska HDP na obyvatele v letech 2000 - 2016; Zdroj: Eurostat (2020), vlastní zpracování. Pozn.: Index změny byl sestaven na základě dynamiky růstu HDP na obyvatele v paritě kupni sily venkovské oblasti, vydělené průměrnou dynamikou rüstu HDP na obyvatele v paritě kupní síly venkovských regioni

na úrovni jednotlivých státu. 
Ve třetí části se zaměříme na hodnocení volatility HDP a změnu zaměstnanosti odvětvové struktury, jakožto možný vysvětlující faktor regionální odolnosti a volatility. Mezi regiony s vysokou volatilitou HDP patřily venkovské regiony v Rumunsku. Vyšší volatility HDP překvapivě dosáhly regiony s vyšším podílem zaměstnanosti v primárním sektoru např. Giurgiu, Neamt a Vaslui, které ve sledovaném období 2008 - 2016 zaznamenaly výrazný pokles zaměstnanosti v primárním sektoru a vysokou dynamiku růstu produktivity práce a ekonomické výkonnosti $\mathrm{v}$ (post)krizovém období. $\mathrm{Z}$ těchto důvodů pravděpodobně primární sektor (zejména zemědělství) nehrál v rumunských venkovských regionech předpokládanou stabilizační roli. Oprea et al. (2020) nezjistili statistický významný vliv specializace na zemědělství na ekonomickou odolnost ani v jiných středoevropských a východoevropských regionech. Nižší volatilitu HDP měly regiony více industrializované s vyšší ekonomickou výkonností v rámci Rumunska např. Bihor, Covasna a Harghita.

Nejvyšší volatilitu v Itálii vykázaly hospodářsky rozvinuté a specializované venkovské regiony Bolzano a Belluno z důvodu rychlého zotavení a vysoké dynamikou růstu HDP v (post)krizovém období. Vyšší volatilitu HDP měly také méně odolné venkovské regiony ve střední Itálii a Sardinii. Lze předpokládat, že v první skupině byla volatilita způsobena výkyvy poptávky po exportně orientovaném zpracovatelském průmyslu, v druhé skupině snížením konkurenceschopnosti a výkyvy cestovního ruchu.

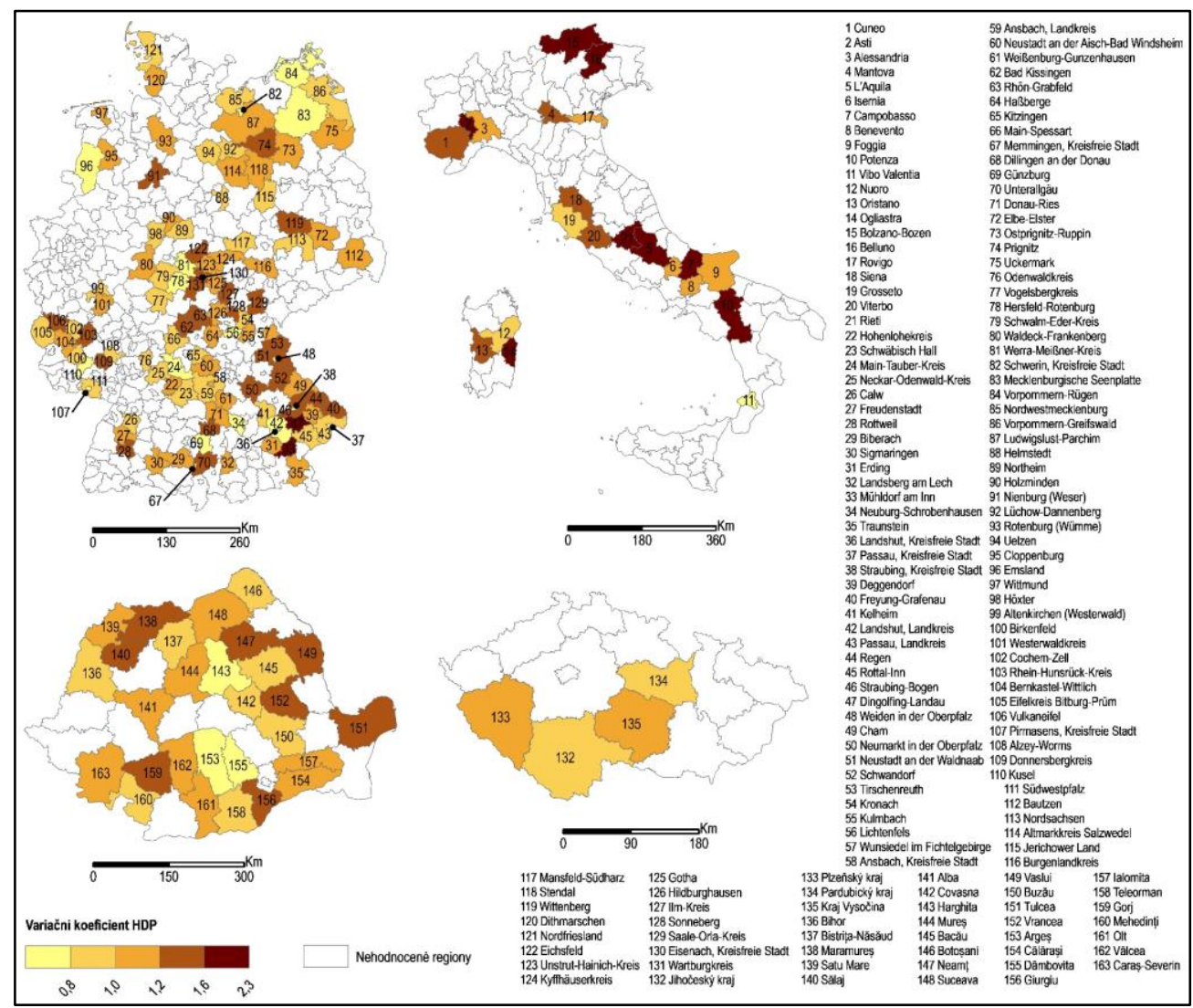

Obr. 3. Variačni koeficient HDP venkovských regionů NUTS3 v letech 2008-2016; Zdroj: Eurostat (2020), vlastní zpracování. Pozn.: Kartogram se vztahuje pouze $k$ venkovským oblastem NUTS3 vymezené dle metodiky Eurostat (2018). Výsledky volatility (variačního koeficientu) HDP venkovských regionů $v$ (post)krizovém obdobi byly vydèleny prümérnými hodnotami na úrovni jednotlivých státu. Variační koeficient HDP italských regionů byl měren v letech 2007 - 2016. 
Nejstabilnější vývoj ekonomické výkonnosti byl charakteristický pro německé venkovské regiony. Na druhou stranu byly v Německu zjištěny nejvyšší regionální rozdíly z hlediska variability HDP v (post)krizovém období, nebot' kromě řady stabilních se vyskytovaly i venkovské regiony s vysokou hodnotou variačního koeficientu HDP, vyplývající z vysoké dynamiky ekonomického růstu v (post)krizovém období: a) některé hospodářsky zaostávající, avšak konvergující regiony, např. Donnersbergkreis, Freyung-Grafenau, Eichsfeld, b) hospodářsky rozvinuté a rychle rostoucí regiony, např. Dingolfing-Landau specializovaný na automobilový průmysl, c) hospodářsky rozvinuté venkovské oblasti citlivé na ekonomické otřesy, které se rychle zotavily, např. Hohenlohekreis.

České venkovské regiony se vyvíjely podobně jako jejich bavorské protějšky. Nízkou volatilitu zaznamenal Jihočeský kraj, možná díky vyššímu podílu zaměstnaných osob v zemědělství a službách. Opakem byl vysoce industrializovaný kraj Vysočina se silnou pozicí velkých zahraničních průmyslových korporací, který byl volatilní navzdory poměrně vysokému podílu zemědělství a lesnictví na zaměstnanosti. Vyšší volatilita byla charakteristická též pro Plzeňský kraj, důvodem byl pokles HDP v druhé vlně ekonomické recese v roce 2012 (viz Ženka et al. 2019). Volatilitu HDP znázorňuje obr. 3.

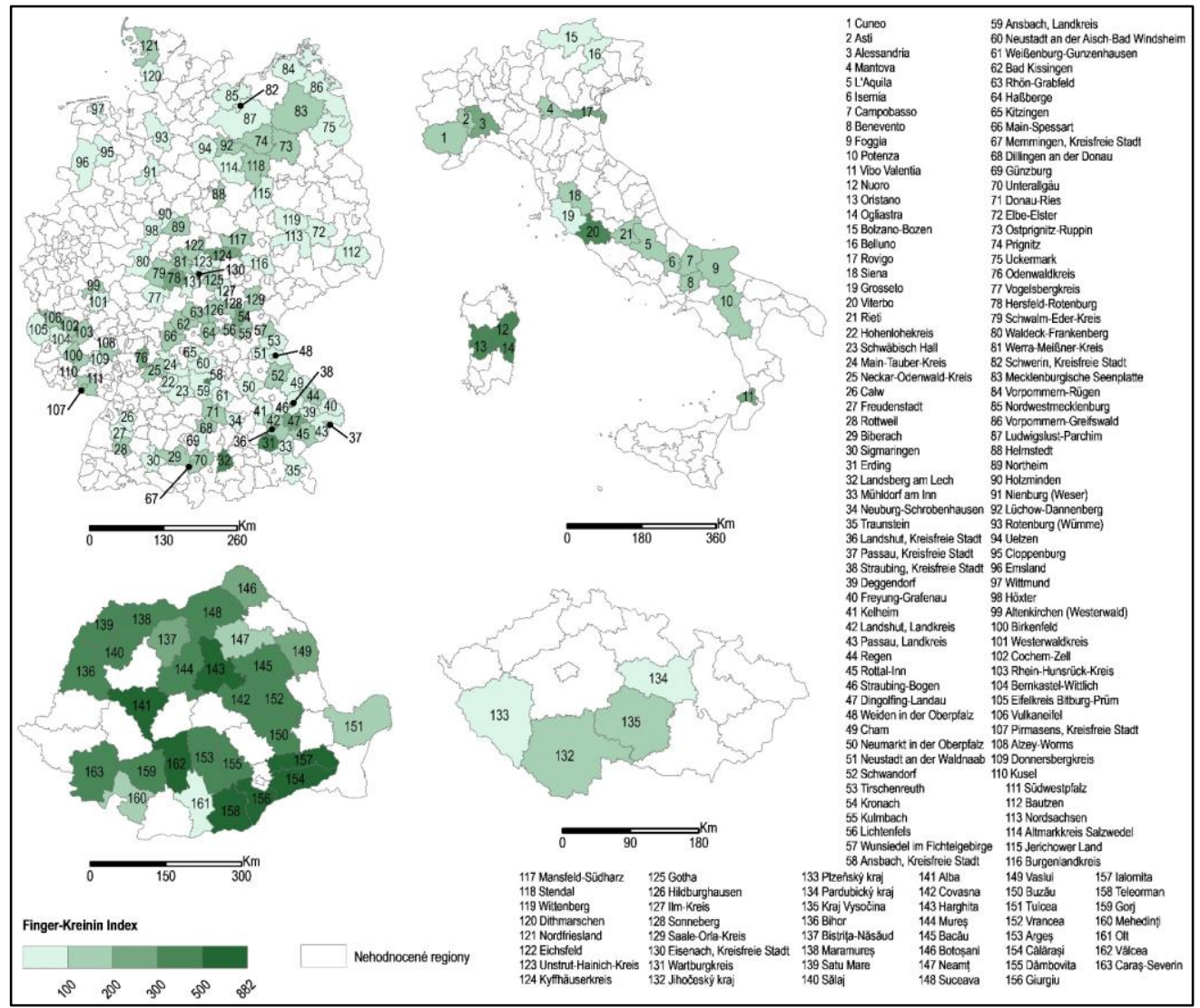

Obr. 4. Změna specializace FKI venkovských regionů NUTS3 v letech 2008 - 2016; Zdroj: Eurostat (2020), vlastní zpracování. Pozn. Změna specializace FKI italských regionů byla měrena v letech 2007 - 2016. 
Dopady globální ekonomické recese byly provázeny změnami v odvětvové struktuře zaměstnanosti. Neprokázali jsme však souvislost mezi odolností a změnami odvětvové struktury. Neplatí předpoklad, že se všechny ekonomicky odolné regiony vyznačovaly vysokou intenzitou strukturálních změn a oživení dosáhly díky přechodu k odvětvím s vy̌šsí přiidanou hodnotou, nebo naopak díky stabilitě odvětvové struktury. Intenzita změn odvětvové struktury však souvisela s volatilitou ekonomické výkonnosti. V jižní Itálii a zejména Rumunsku byla vysoká volatilita HDP spojená s významnými strukturálními změnami, poklesem primárního sektoru ve prospěch zejména sektoru služeb (Rumunsko) nebo výrazným růstem veřejných služeb (Itálie). Venkovské regiony v Rumunsku a Itálii navíc dosáhly celkového poklesu zaměstnanosti v období 2008 - 2016, což naznačuje úbytek a stárnutí obyvatelstva na venkově.

Poměrně jednoznačným zjištěním je stabilizační role veřejných služeb. V Česku, Německu a Itálii byl naměřen nárůst počtu zaměstnanců ve veřejném sektoru $\mathrm{v}$ (post)krizovém období, zároveň italské venkovské regiony s vyšším podílem zaměstnanosti v primárním sektoru a veřejných službách zaznamenaly nižší volatilitu HPD. V Rumunsku jsme zaznamenali přizpůsobování kapacit potřebám území a pokles zaměstnanosti ve veřejných službách, související s populačním úbytkem venkovských regionů. Změnu specializace odvětví na venkově zachycujeme v obr. 4 .

$\mathrm{Na}$ základě výše uvedených výsledků jsme vytvořili typologii regionů NUTS3 v letech $2008-2016 \mathrm{z}$ hlediska kombinace odolnosti a volatility. Typologii venkovských regionů předkládá obr. 5.

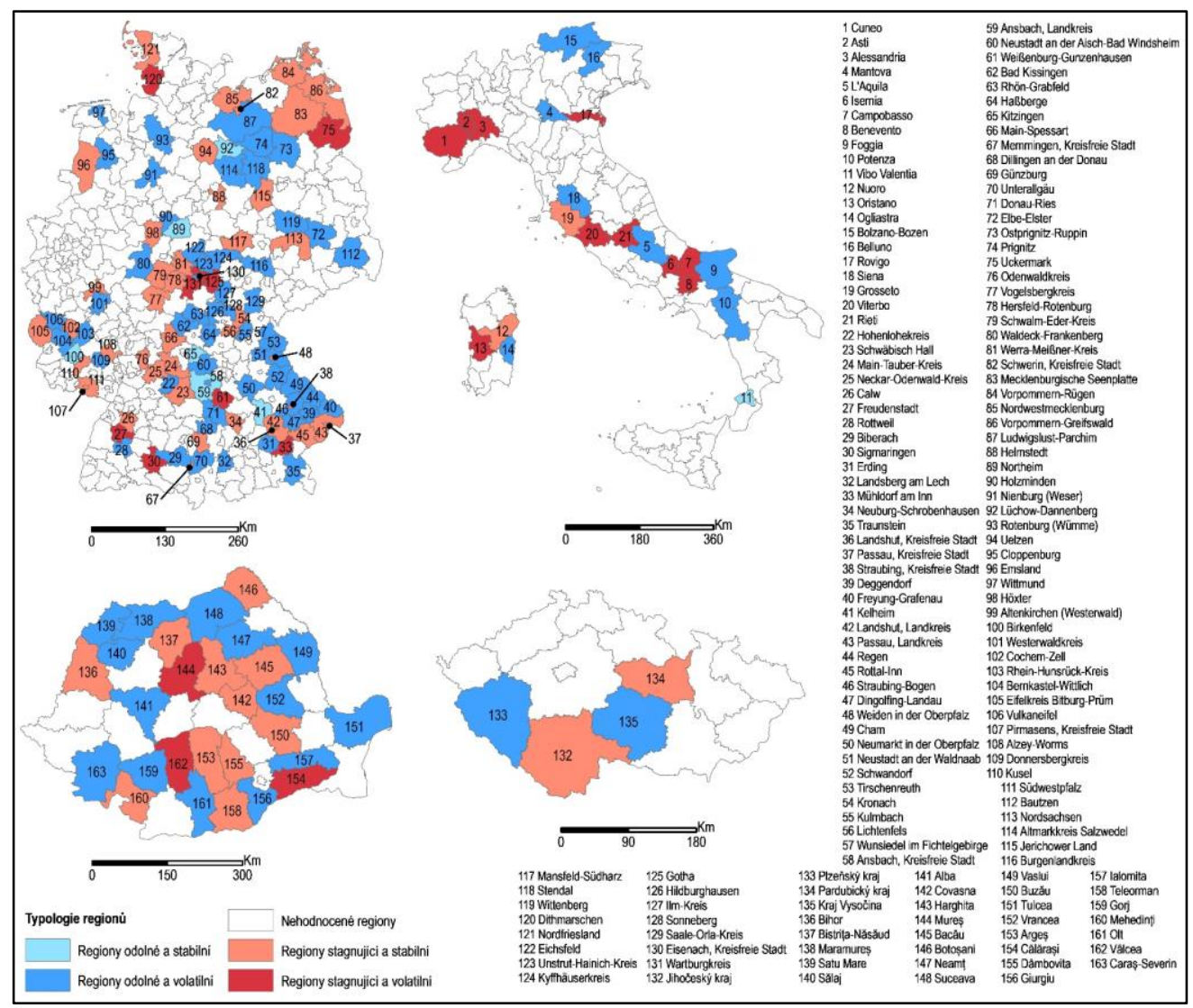

Obr. 5. Typologie venkovských regionů NUTS3 z hlediska dynamiky a volatility HDP v letech 2008 - 2016 (v Itálii 2007 - 2016); Zdroj: Eurostat (2020), vlastní zpracování 
Nejméně zastoupen byl typ „regiony odolné a stabilní“ - nadprůměrný růst HDP a nízká volatilita HDP. Platilo pouze pro 6 regionů v Německu a jeden v Itálii (Vibo Valentia). Všechny měly podprůměrné HDP ve sledovaném období. Druhý typ „regiony odolné a volatilni'“ - nadprůměrný růst HDP a vysoká volatilita HDP. Tento typ převažoval v Německu a často souvisel s výchozím vyšším HDP. Celkem bylo zaznamenáno 79 venkovských regionů v daném typu. Třetí typ „regiony stagnující a stabilní“ je typický podprůměrným růstem HDP a nízkou volatilitou HDP. Druhý a třetí typ byl nejčastěji zastoupen ve venkovských oblastech v Česku a Rumunsku. Čtvrtý typ „Regiony stagnující a volatilní“ převažoval v Itálii. Vyjma oblastí ležících na severu měly všechny regiony podprůměrné HDP a zároveň se v príípadě regionů ve stř̌ední Itálii a Sardinii jednalo o nejméně odolné regiony ze studovaného vzorku. Mimo Itálii se tento typ nacházel také v Rumunsku (Mures, Vâlcea a Calarasi) a Německu (např. Uckermark, Dithmarschen, Weißenburg-Gunzenhausen). Typologii venkovských regionů předkládá obr. 5.

\section{Diskuze}

Dopady recese na hospodářský vývoj venkovských regionů byly diferencované. Disparity mezi regiony spočívaly v načasování, délce trvání i účinnosti hospodářského otřesu (viz Fratessi, Perucca 2018). Míra odolnosti a volatility HDP venkovských regionů v (post)krizovém období byla ovlivňována národní úrovní. Uvnitř jednotlivých států se vyskytovaly venkovské regiony s podobnou mírou odolnosti a volatility HDP, což potvrzuje předpoklady Fratesiho a Perucci (2018) o vlivu makroekonomických trendů na odolnost regionů. V souladu s Ezcurrou a Riosem (2019) a Giannakisem a Bruggeman (2019) jsme zjistili, že vysoce odolné regiony byly obklopené dalšími vysoce odolnými regiony - platilo pro Německo, severní Itálii a částečně také Česko, naproti tomu neodolné regiony obklopené neodolnými regiony se koncentrovaly ve střední Itálii, Sardinii a Rumunsku (viz též Staníčková, Melecký 2018).

V souladu s teoretickými předpoklady Giannakise a Bruggeman (2019), Fratesiho et al. (2016) a Daviese (2011) byla zjištěna vyšší volatilita venkovských regionů specializovaných na zpracovatelský průmysl ve všech státech. Je nutno podotknout, že toto pravidlo není zdaleka univerzální, některé regiony kombinovaly vyšší specializaci na zpracovatelský průmysl s nízkou volatilitou např. italská Alessandria nebo rumunský Bihor, Covasna a Harghita. Vyšší citlivostí byly charakteristické regiony s exportně orientovanými odvětvími zpracovatelského průmyslu, zastoupenými zejména pobočnými závody nadnárodních korporací. Projevil se vliv tzv. syndromu pobočných závodů (viz Sonn, Lee 2012). Tento efekt byl patrný zejména v př́ípadě rumunských venkovských regionů. V mnohem menší míre byl zaznamenán i v českých venkovských krajích, pro které je typické velmi omezené zastoupení ředitelství velkých firem. Tato se soustřed’ují v Praze a Středočeském, s velkým odstupem též v Moravskoslezském a Ústeckém kraji (Sucháček et al. 2018).

Pavlínek a Ženka (2010) také zjistili negativní dopady recese na automobilový průmysl v Česku, kdy zahraniční firmy nejčastěji redukovaly pracovní místa, avšak nedocházelo k úplnému uzavření nebo přemístění závodu. Tyto předpoklady mohou také přispět k vysvětlení vyšší volatility HDP v Plzeňském a Pardubickém kraji a kraji Vysočina. Naše výsledky potvrzují závěry Ženky et al. (2019), že v Česku byly v první vlně recese zasaženy převážně venkovské oblasti závislé na exportně orientované výrobě, která v předkrizovém období přilákala velké množství př́mých zahraničních investic, většina $\mathrm{z}$ těchto zahraničních firem se $\mathrm{v}$ (post)krizovém období zotavila relativně rychle.

Ve venkovských oblastech vybraných států docházelo k oslabování významu tradičních odvětví a posunu $\mathrm{k}$ technologicky a kapitálově náročným odvětvím zpracovatelského průmyslu s vyšší přidanou hodnotou nebo službám (evidence za Česko - Pavlík 2018). Nejvýznamněji se tento trend projevil v Rumunsku, ale jedná se o trend patrný v celé střední Evropě (viz též Lengyel et al. 2017 pro situaci v Mad’arsku). Rumunské venkovské regiony procházely 
tak intenzivní restrukturalizací, že vysoká zaměstnanost v primárním sektoru neplnila stabilizační funkci. Venkovské regiony v Rumunsku a Itálii dosáhly celkového poklesu zaměstnanosti v období 2008 - 2016, což naznačuje úbytek a obecně nízkou odolnost. Podle studií Giannakis, Bruggeman (2019) a Pavel, Moldovan (2019) patří příznivé demografické trendy mezi zásadní faktory regionální ekonomické odolnosti v EU. Italské venkovské regiony $\mathrm{s}$ vyšším podílem zaměstnanosti v primárním sektoru a veřejných službách zaznamenaly nižší volatilitu ekonomické výkonnosti. V Česku, Německu a Itálii se v (post)krizovém období zvýšil počet zaměstnaných osob ve veřejných službách. Těmito výsledky lze potvrdit předpoklady Ezcurry (2011), Fratesiho a Rodrígueze-Pose (2016) o stabilizační roli veřejného sektoru.

\section{Závěr}

V tomto článku jsme věnovali pozornost ekonomické odolnosti venkovských regionů NUTS3 v Česku, Itálii, Německu a Rumunsku. Zjistili jsme, že venkovské regiony byly vysoce heterogenní z hlediska dynamiky růstu a reakce na hospodářský otřes. Mezi významné faktory ekonomické odolnosti regionů patřily př́iznivé národní makroekonomické trendy, geografická blízkost odolných regionů a odvětvová struktura hospodářství. Diverzifikované terciarizované venkovské regiony s rozvinutou průmyslovou základnou (zejména v Německu a severní Itálii) byly v průměru odolnější než regiony s významným podílem primárního sektoru na počátku sledovaného období, které se nacházely zejména v Rumunsku. Německé i české venkovské regiony dosáhly v poměrně krátké době plného zotavení z hlediska HDP a později také zaměstnanosti. Intenzivní pokles zaměstnanosti v primárním sektoru a přesun pracovních míst do sekundéru a terciéru byly v rumunských regionech spojeny s vysokou volatilitou ekonomické výkonnosti, v Itálii s růstem podílu veřejného sektoru na zaměstnanosti.

Typologie venkovských regionů podle kombinace ekonomické odolnosti a volatility odhalila mozaikovitý regionální vzorec s velmi obtížně identifikovatelnými zákonitostmi. Jen velmi málo regionů (většina z nich byla v Německu) rostlo v období 2000 - 2016 nadprůměrným tempem bez výrazných výkyvů v ekonomické výkonnosti. Na druhou stranu nejméně žádoucí scénář (stagnace a volatilita) byl charakteristický též pro poměrně malý počet regionů, z nichž většina se nacházela $v$ Itálii. Nejčastější byly tedy regiony odolné a volatilní, dále regiony stagnující, ale poměrně stabilní. Celkové výsledky rozhodně zpochybňují zjednodušující představu venkovských regionů jako ekonomicky sice méně dynamických, ale stabilních jednotek těžících z tlumícího vlivu necyklických odvětví a veřejného sektoru.

Vzhledem k vysoké vnitřní heterogenitě venkovských regionů doporučujeme provést srovnání venkovských regionů na nižší prostorové úrovni: LAU1 nebo LAU2 (viz např. Urso et al. 2019 nebo Ženka et al. 2019). Nevíme, do jaké míry byl vývoj venkovských regionů tažen urbánními jádry, a do jaké míry venkovskými zázemími. Limitem je však obtížná dostupnost a srovnatelnost ekonomických dat na mikroregionální úrovni. Zcela aktuálním směrem př́ípadného výzkumu mohou být dopady pandemie na ekonomiku venkovských regionů, které by vzhledem k nižší hustotě zalidnění, vyššímu podílu primárního sektoru a fragmentované velikostní struktuře firem měly být postiženy méně než vysoce urbanizované oblasti. Zároveň je možné testovat hypotézu, že negativní dopady pandemie a s ní související vládní opatření omezující přeshraniční mobilitu pracovní síly mohou zásadním způsobem ovlivňovat produktivitu ekonomiky venkova v pohraničních oblastech více než ve vnitrozemí.

V souladu s výsledky a diskuzí navrhujeme několik politických doporučení zaměřených na posílení odolnosti venkovských regionů: a) opatření směřující ke stabilizaci obyvatelstva na venkově, prohlubování kvalifikace a zvyšování kvality lidských zdrojů, b) podporu necyklických odvětví a mimoprodukčních funkcí, které alespoň částečně kompenzují volatilitu zpracovatelského průmyslu a obchodních služeb ve správních městech, c) opatření posilující ekonomickou provázanost správních měst s venkovskými zázemími, která mohou stimulovat šíření rozvojových impulsů z měst do venkovských oblastí a zároveň zvýší komplementaritu ekonomických aktivit ve městech a venkovských obcích daného regionu. 


\section{Literatura}

ANNONI, P., DE DOMINICIS, L., KHABIRPOUR, N. 2019: Location matters: A spatial econometric analysis of regional resilience in the European Union. Growth and Change, 50(3), 824-855. DOI: https://doi.org/10.1111/grow.12311.

BLAŽEK, J., NETRDOVÁ, P. 2012: Regional unemployment impacts of the global financial crisis in the new member states of the EU in Central and Eastern Europe. European Urban and Regional Studies, 19(1), 42-61. DOI: https://doi.org/10.1177/0969776411428650.

CAINELLI, G., GANAU, R., MODICA, M. 2019: Industrial relatedness and regional resilience in the European Union. Papers in Regional Science, 98(2), 755-778. DOI: https://doi.org/10.1111/pirs.12377.

CAPELLO, R., CARAGLIU, A., FRATESI, U. 2015: Spatial heterogeneity in the costs of the economic crisis in Europe: are cities sources of regional resilience? Journal of Economic Geography, 15(5), 951-972. DOI: https://doi.org/10.1093/jeg/lbu053.

CASI, L., RESMINI, L. 2011: The spatial distribution of FDI across European regions: does a country effect exist. Forum for Research in Empirical International Trade, 1-26.

DAVIES, S. 2011: Regional resilience in the 2008-2010 downturn: comparative evidence from European countries. Cambridge Journal of Regions, Economy and Socienty, 4(3), 369-382. DOI: https://doi.org/10.1093/cjres/rsr019.

DISSART, J., C. 2003: Regional economic diversity and regional economic stability: research results and agenda. International Regional Science Review, 26(4), 423-446. DOI: https://doi.org/10.1177/0160017603259083.

EUROFOND 2019: European Restructuring Monitor. [cit. 2020-03-17]. Retrieved from: https://www.eurofound.europa.eu/observatories/emcc/erm/factsheets.

EUROSTAT 2018: Urban-rural typology methodology. [cit. 2020-01-25]. Retrieved from: https://ec.europa.eu/eurostat/web/rural-development/methodology.

EUROSTAT 2020: NUTS 3 level data. [cit. 2020-02-04]. Retrieved from: https://ec.europa.eu/ eurostat/web/rural-development/data.

EZCURRA, R. 2011: Unemployment volatility and regional specialization in the European Union. Regional Studies, 45, 1121-1137. DOI: https://doi.org/10.1080/ 00343401003713332.

EZCURRA, R., RIOS, V. 2019: Quality of government and regional resilience in the European Union. Evidence from the Great Recession. Papers in Regional Science, 98, 1267-1290. DOI: https://doi.org/10.1111/pirs.12417.

FAGGIAN, A., GEMMITI, R., JAQUET, T., SANTINI, I. 2018: Regional economic resilience: the experience of the Italian local labor systems. Annals of Regional Science, 60(2), 393-410. DOI: https://doi.org/10.1007/s00168-017-0822-9.

FINGER, J., M., KREININ, M., E. 1979: A Measure of Export Similarity'and Its Possible Uses. The Economic Journal, 89(356), 905-912. DOI: https://doi.org/10.2307/2231506.

FRATESI, U., PERUCCA, G. 2018: Territorial capital and the resilience of European regions. The Annals of Regional Science, 60(2), 241-264. DOI: https://doi.org/10.1007/s00168-017-0828-3.

FRATESI, U., RODRÍGUEZ-POSE, A. 2016: The crisis and regional employment in Europe: what role for sheltered economies? Cambridge Journal of Regions, Economy and Society, 9(1), 33-57. DOI: https://doi.org/10.1093/cjres/rsv032.

GIANNAKIS, E., BRUGGEMAN, A. 2019: Regional disparities in economic resilience in the European Union across the urban-rural divide. Regional Studies, 54(9), 1200-1213. DOI: https://doi.org/10.1080/00343404.2019.1698720.

LENGYEL, I., VAS, Z., SZAKALNE KANO, I., LENGYEL, B. 2017: Spatial differences of reindustrialization in a post-socialist economy: manufacturing in the Hungarian counties. European Planning Studies, 25, 1416-1434. DOI: https://doi.org/10.1080/09654313.2017.1319467. 
MARTIN, R. 2012: Regional economic resilience, hysteresis and recessionary shocks. Journal of Economic Geography, 12(1), 1-32. DOI: https://doi.org/10.1093/jeg/lbr019.

MARTIN, R., SUNLEY, P., GARDINER, B., TYLER, P. 2016: How regions react to recessions: Resilience and the role of economic structure. Regional Studies, 50(4), 561-585. DOI: https://doi.org/10.1080/00343404.2015.1136410.

MARTIN, R., SUNLEY, P., TYLER, P. 2015: Local growth evolutions: recession, resilience and recovery. Cambridge Journal of Regions, Economy and Society, 8(2), 141-148. DOI: https://doi.org/10.1093/cjres/rsv012.

OPREA, F., ONOFREI, M., LUPU, D., VINTILA, G., PARASCHIV, G. 2020: The Determinants of Economic Resilience. The Case of Eastern European Regions. Sustainability, 12(10). DOI: https://doi.org/10.3390/su12104228.

ÖNNERFORS, Å., KOTZEVA, M., BRANDMÜLLER, T. 2019: Eurostat regional yearbook 2019 edition. Luxembourg (Publications Office of the European Union). DOI: https://doi.org/10.2785/1522.

PAVEL, A., MOLDOVAN, O. 2019: Determining local economic development in the rural areas of Romania. Exploring the role of exogenous factors. Sustainability, 11(1), 1-24. DOI: https://doi.org/10.3390/su11010282.

PAVLÍK, A. 2016: Odolnost českých nemetropolitních regionů. In Nováček, A. ed. Geografické myšlení jako aktuální společenská výzva. České Budějovice (Jihočeská univerzita), pp. 204-216.

PAVLÍK, A. 2018: Odolnost a restrukturalizace ekonomických aktivit ve venkovských oblastech Česka v postkrizovém období 2009-2014. In Klímová, V., Žítek, V. eds. XXI. mezinárodni kolokvium o regionálních vědách sbornik přispěvků. Brno (Masarykova univerzita), pp. 368-373. DOI: https://doi.org/10.5817/CZ.MUNI.P210-8970-2018-48.

PAVLÍNEK, P., ŽENKA, J. 2010: The 2008-2009 automotive industry crisis and regional unemployment in Central Europe. Cambridge Journal of Regions, Economy and Society, 3(3), 349-365. DOI: https://doi.org/10.1093/cjres/rsq026.

REINHART, C., M., ROGOFF, K., S. 2009: The aftermath of financial crises. American Economic Review, 99(2), 466-472. DOI: https://doi.org/10.1257/aer.99.2.466.

SLACH, O., ŽENKA, J. 2017: Post-Crisis Spatial Development of Creative Industries: Evidence from Czechia. In Chapain, C., Stryjakiewicz, T. eds. Creative Industries in Europe. Cham (Springer). DOI: https://doi.org/10.1007/978-3-319-56497-5_10.

SONN, J., W., LEE, D. 2012: Revisiting the branch plant syndrome: Review of literature on foreign direct investment and regional development in Western advanced economies. International Journal of Urban Sciences, 16(3), 243-259, DOI: https://doi.org/ 10.1080/12265934.2012.733589.

STANÍČKOVÁ, M., MELECKÝ, L. 2018: Understanding of resilience in the context of regional development using composite index approach: The case of European Union NUTS-2 regions. Regional Studies, Regional Science, 5(1), 231-254. DOI: https://doi.org/ 10.1080/21681376.2018.1470939.

SUCHÁČEK, J, URMINSKÝ, J., ŠKAPA, S. 2018: The spatial distribution of largest firms in the Czech Republic and its managerial implications. GeoScape, 12(2), 76-83. DOI: https://doi.org/10.2478/geosc-2018-0008.

URSO, G., MODICA, M., FAGGIAN, A. 2019: Resilience and sectoral composition change of italian inner areas in response to the great recession. Sustainability, 11(9). DOI: https://doi.org/10.3390/su11092679.

VACULÍK, M., PÁSZTO, V., ŠVARCOVÁ, B. (2017): Spatial distribution of innovation activities in Czech Republic, 2010-2012. Journal of International Studies, 10(1), 123-134. DOI: https://doi.org/10.14254/2071-8330.2017/10-1/8. 
ŽENKA J., PAVLÍK A., SLACH O. 2017: Resilience of metropolitan, urban and rural regions: a Central European perspective. GeoScape, 11(1), 25-40. DOI: https://doi.org/ 10.1515/geosc-2017-0003.

ŽENKA, J., SLACH, O., PAVLÍK, A. 2019: Economic resilience of metropolitan, old industrial, and rural regions in two subsequent recessionary shocks. European Planning Studies, 27(11), 2288-2311. DOI: https://doi.org/10.1080/09654313.2019.1638346.

ŽENKA, J., SLACH, O., SOPKULIAK, A. 2017: Typologie českých nemetropolitních regionů z hlediska faktorů, mechanismů a aktérů regionálního rozvoje. Geografie, 122(3), 281-309.

Př́spěvek byl zpracován v rámci grantu SGS17/PřF/2020 SMART cities a inovativních př́istupy $k$ rozvoji měst a regionů.

\author{
Adresy autorov \\ Mgr. Adam Pavlík, Ph.D. \\ Katedra sociální geografie a regionálního rozvoje, \\ Př́rodovědecká fakulta, Ostravská univerzita \\ Chittussiho 10, 71000 Ostrava \\ Česká republika \\ Pavlik.A@email.cz \\ doc. RNDr. Jan Ženka, Ph.D. \\ Katedra sociální geografie a regionálního rozvoje, \\ Př́rodovědecká fakulta, Ostravská univerzita \\ Chittussiho 10, 71000 Ostrava \\ Česká republika \\ Jan.Zenka@osu.cz
}

